\title{
The effect of childhood trauma, ApoE genotype and HIV-1 viral protein R variants on change in cognitive performance
}

\author{
Jacqueline S. Womersley ${ }^{1,2^{*}}$ (D), Lara B. Clauss ${ }^{1,3}$, Olivette Varathan ${ }^{4}$, Susan Engelbrecht ${ }^{4,5}$, Sian M. J. Hemmings ${ }^{1,2}$, \\ Soraya Seedat ${ }^{1,2}$ and Georgina Spies ${ }^{1,2}$
}

\begin{abstract}
Objective: Gene-environment interactions contribute to the development of HIV-associated neurocognitive disorders. We examined whether childhood trauma, apolipoprotein $\mathrm{E}$ isoforms and viral protein R (Vpr) variants were associated with change in cognitive performance. Seventy-three seropositive women completed neuropsychological assessments at baseline and 1-year follow-up. We conducted genetic analyses using DNA obtained from blood and calculated risk scores based on Vpr amino acid 37, 41 and 55 variants that were previously associated with cognitive performance.
\end{abstract}

Results: Global cognitive scores declined significantly over the 1-year study period ( $p=0.029$ ). A reduction in global cognitive scores was associated with childhood trauma experience $(p=0.039)$.

Keywords: Apolipoprotein E, Childhood trauma, HIV-associated neurocognitive disorders, Viral protein $\mathrm{R}$

\section{Introduction}

HIV-associated neurocognitive disorders (HAND) describe a spectrum of cognitive, behavioural and motor disturbances that may occur secondary to HIV infection [1]. Though improvement in and increased access to antiretroviral therapy (ART) has reduced the severity of HAND, milder forms persist and may affect up to $50 \%$ of the estimated 36.9 million people infected with HIV worldwide [1-3]. There is thus a need to identify genetic and environmental factors that increase the risk of developing HAND.

Genetic variation in the gene encoding apolipoprotein E $(A p o E)$ has been suggested to contribute to HAND [4-6]. Two single nucleotide polymorphisms (rs7412 and rs429358) that encode $\mathrm{C} / \mathrm{T}$ transitions give rise to

\footnotetext{
*Correspondence: jsw1@sun.ac.za

${ }^{1}$ Department of Psychiatry, Faculty of Medicine and Health Sciences, Stellenbosch University, Francie van Zijl Drive, Tygerberg 7505, South Africa

Full list of author information is available at the end of the article
}

cysteine/arginine amino acids at residue positions 112 and 158, the combination of which designates three isoforms i.e. ApoE $\varepsilon 2, \varepsilon 3$ and $\varepsilon 4$ [7]. This genetic variation, specifically the $\varepsilon 4$ isoform, may affect HIV infection [8] and replication in the brain [9], as well as susceptibility to HIV-related neurotoxic proteins [10]. Viral genetic variation may also contribute to HAND, with a study by Dampier et al. [11] identifying three amino acids (AAs) in viral protein $\mathrm{R}(\mathrm{Vpr})$ that affect neurocognitive performance. This 96-AA accessory protein plays a role in HIV infection and viral transcription, and may contribute to neuronal apoptosis, synaptic loss, proinflammatory signalling, oxidative stress and blood-brain barrier permeability [12-17]. Childhood trauma (CT) occurs during a period of rapid neurodevelopment and maturation, potentially exerting long-term consequences on neurobiology and mental health $[18,19]$. Accordingly, CT has been identified as a predictor of poorer cognitive performance in women living with HIV [20-22]. 
The aetiology of HAND is complex and multifactorial. We examined the associative and interactive effects of $\mathrm{CT}$ and variation in $A p o E$ and $\mathrm{Vpr}$ on cognitive function over a 1-year period in a cohort of South African women living with HIV.

\section{Main text \\ Methods \\ Study design and participants}

This was a nested study of an investigation of the biological endophenotypes of HIV and CT. Seventy-three women who met the study inclusion criteria [20] were recruited from community health care centres in Cape Town between 2008 and 2016. The study was approved by the Stellenbosch University Health Research Ethics Committee and written informed consent was obtained from all participants.

\section{Clinical assessments}

Participants provided sociodemographic data and were assessed for the presence of psychiatric disorders with the MINI-International Neuropsychiatric Interview-Plus [23]. Neurocognitive testing was done at baseline and 1-year with the HIV Neurobehavioral Research Center Neuropsychological (NP) battery [24], which taps into seven domains of cognitive function: motor ability, processing speed, verbal fluency, learning, delayed recall, attention/working memory and executive function. Raw scores from the seventeen NP tests were used to generate an age- and education-adjusted global cognitive z-score [20]. The 28-item Childhood Trauma Questionnaire-Short Form (CTQ-SF) was administered at baseline to assess for $\mathrm{CT}$ experienced prior to 18 years of age [25]. HIV infection was confirmed using enzyme-linked immunosorbent assays.

\section{Apolipoprotein E genotyping}

Genotyping for $A p o E$ was performed as previously described [6]. DNA extracted from whole blood was subjected to $\mathrm{KASP}^{\circledR}$ genotyping technology (LGC, Middelsex, UK) for the two $A p o E$ variants rs7412 and rs429358. Genotyping was successfully undertaken for 62 participants.

\section{Viral protein $R$ amino acid assessment}

Polymerase chain reaction (PCR) using DNA obtained from whole blood at 1-year follow-up and primers (Integrated DNA Technologies, Coralville, IO) flanking the region of interest was performed, and the resulting amplicons were cleaned using the Wizard SV Gel and PCR Clean-up System (Promega, Fitchburg, WI). Eluted samples were subjected to a sequencing PCR reaction using the BigDye Terminator v3.1 Cycle Sequencing kit (Applied Biosystems, Carlsbad, CA) and automated Sanger sequencing was performed on the $3130 \times \mathrm{L}$ Genetic Analyser (Applied Biosystems, Carlsbad, CA). Sequences were manually quality checked and assembled using Sequencher 5.4.6 (Gene Code Corporation, Ann Arbor, MI) with a minimum overlap of 1 and a minimum match of 60. Sequences were aligned and trimmed to contain Vpr bases using Geneious version 10.1.3 (Biomatters, Auckland, New Zealand). The trimmed sequences were submitted to Los Alamos National Laboratory for quality control and initial subtyping. Sequence subtyping was conducted using four online tools: Context-based Modelling for Expeditious Typing HIV-1 [26], jumping profile Hidden Markov Models [27], REGA HIV Subtyping Tool version 3 [28] and Recombinant Identification Program [29]. Vpr AA identification was successfully performed for 66 participants.

\section{Statistical analyses}

Demographic and clinical characteristics according to $\mathrm{CT}$ exposure (CTQ-SF score $>40$ indicative of at least mild-to-moderate CT exposure) were assessed using Student's t-tests, Mann-Whitney U tests or Pearson Chi square tests. As viral load data were highly skewed, we generated log-transformed data for subsequent analyses. Genotyping results were used to classify participants according to the presence of the $\varepsilon 4$ isoform i.e. heteroand homozygous individuals were grouped. We classified AAs according to their effects on cognition, as reported by Dampier et al. [11], with higher scores indicative of greater risk. Accordingly, the AAs were scored as follows: AA37 I (neuroprotective) variant $=0$, other (neutral) variants $=1 ;$ AA41 $S$ (neuroprotective) variant $=0, \mathrm{~N}$ (risk) variant $=2$, other (neutral) variants $=1$; and AA55 A (risk) variant $=1$, other (neutral) variants $=0$. A composite risk score was generated by summing the values assigned to the three AAs. Repeated measures analyses with 1-year global cognitive score as the outcome measure, baseline global cognitive score as a predictor and continuous CTQ-SF scores, ApoE $\varepsilon 4$ carrier status, and individual and composite AA risk scores as between subject factors in regression models were performed. We examined whether including interactions between predictor variables explained more of the variation in our data by using ANOVA to compare the fit of the models produced using factors or factors plus their interaction effects. As CD4 and CD8 lymphocyte counts, as well as both original and log-transformed viral load values were not associated with global cognitive scores, these parameters were not included as covariates. All statistical analyses were performed in R [30] and an alpha value of less than 0.05 was deemed statistically significant. 


\section{Results}

\section{Demographic and clinical characteristics}

Neurocognitive assessments at baseline and follow-up were completed by 73 women (mean age 35.23 years) who self-identified as "Black, isiXhosa-speaking". Approximately three-quarters of the sample (76.7\%) were on ART. Based on the 63 women who provided their year of diagnosis, the mean time since confirmed HIV infection was 13.13 years. A repeated measures $t$ test comparing global cognitive scores at baseline (mean $=-0.02$, standard deviation $=0.55$ ) and followup (mean $=-0.12$, standard deviation $=0.53$ ) indicated a significant decline in cognitive scores over the 1 -year study period $(\mathrm{t}(72)=2.22, \mathrm{p}=0.029)$. Most participants ( $\mathrm{n}=54,74 \%$ ) self-reported CT of at least low-to-moderate severity (CTQ-SF $\geq 41$ ). Participants who experienced $\mathrm{CT}$ were more likely to be on ART $(\mathrm{p}=0.001)$ and showed trends towards a lower median level of education $(p=0.052)$ and lower follow-up global cognitive score $(\mathrm{p}=0.064)$. Our assessment of viral load was limited to the 38 individuals (15 without CT and 23 with CT) with a viral load above the detectable level i.e. $\geq 40$ copies/ml. Only analyses that used the original data indicated significantly higher viral loads in participants with CT exposure $(\mathrm{p}=0.023)$. Demographic and clinical data are summarised in Table 1. The CTQ-SF scores ranged from 25 to 114 and were used to categorise participants based on the severity of CT exposure (Table 2).

Table 2 Participants categorisation by childhood trauma severity

\begin{tabular}{|c|c|c|c|c|}
\hline & $\begin{array}{l}\text { None } \\
\text { or minimal } \\
\text { CTQ-SF } \leq 40\end{array}$ & $\begin{array}{l}\text { Low-to-moderate } \\
41 \leq \mathrm{CTQ} \text {-SF } \leq 55\end{array}$ & $\begin{array}{l}\text { Moderate- } \\
\text { to-severe } \\
56 \leq \text { CTQ-SF } \leq 72\end{array}$ & $\begin{array}{l}\text { Severe-to- } \\
\text { extreme } \\
73 \leq \mathrm{CTQ} \text {-SF }\end{array}$ \\
\hline $\begin{array}{l}\text { Number of } \\
\text { par- } \\
\text { ticipants } \\
\text { (\%) }\end{array}$ & $19(26.0)$ & $10(13.7)$ & $17(23.3)$ & $27(37.0)$ \\
\hline
\end{tabular}

Table 1 Baseline demographic and clinical characteristics of study participants by childhood trauma exposure

\begin{tabular}{|c|c|c|c|c|c|c|c|}
\hline & All participants $(n=73)$ & Childhood trauma $(n=54)$ & $\begin{array}{l}\text { No childhood trauma } \\
(n=19)\end{array}$ & $\mathbf{t}$ & $\mathbf{U}$ & $x^{2}$ & $\mathbf{P}$ \\
\hline Mean age in years $\pm S D$ & $35.23 \pm 7.24$ & $35.81 \pm 6.60$ & $33.58 \pm 8.80)$ & -1.16 & & & 0.250 \\
\hline $\begin{array}{l}\text { Median years of education } \\
\text { (interquartile range) }\end{array}$ & $11.00(9.00-11.00)$ & $10.00(9.00-11.00)$ & $11.00(10.00-12.00)$ & & 362.00 & & 0.052 \\
\hline $\begin{array}{l}\text { Median viral load (interquar- } \\
\text { tile range) }\end{array}$ & $\begin{array}{l}18,459.50(1732.25- \\
64,831.75)\end{array}$ & $\begin{array}{l}24,510.00(4478.00- \\
\quad 64,634.50)\end{array}$ & $9759.00(1284.50-50,905.50)$ & & 320.50 & & 0.023 \\
\hline $\begin{array}{l}\text { Median log-transformed } \\
\text { viral load (interquartile } \\
\text { range) }\end{array}$ & $4.26(3.20-4.82)$ & $4.39(3.52-4.81)$ & $3.99(3.08-4.87)$ & & 140.00 & & 0.332 \\
\hline $\begin{array}{l}\text { Median CD4 count (inter- } \\
\text { quartile range) }\end{array}$ & $453.00(270.50-664.25)$ & 432.00 (259.50-643.75) & $481.50(410.25-677.75)$ & & 412.00 & & 0.336 \\
\hline Median CD8 count (range) & 834.00 (620.50-1107.75) & 768.00 (539.00-1090.00) & $1050.00(754.00-1284.00)$ & & 357.50 & & 0.203 \\
\hline On ART treatment & 56 & 47 & 9 & & & 12.38 & 0.001 \\
\hline$A A 37^{b}$ & & & & & & 1.11 & 0.574 \\
\hline 1 & 3 & 3 & 0 & & & & \\
\hline $\mathrm{AA} 41^{\mathrm{b}}$ & & & & & & 2.78 & 0.427 \\
\hline$S$ & 24 & 20 & 4 & & & & \\
\hline N & 12 & 7 & 5 & & & & \\
\hline$A A 55^{b}$ & & & & & & 5.61 & 0.061 \\
\hline A & 13 & 13 & 0 & & & & \\
\hline $\begin{array}{l}\text { Hetero- or homozygous for } \\
\text { the ApoE } \varepsilon 4 \text { allele }\end{array}$ & 26 & 18 & 8 & & & 1.72 & 0.190 \\
\hline $\begin{array}{l}\text { Mean baseline global cogni- } \\
\text { tive score } \pm S D\end{array}$ & $-0.02 \pm 0.55$ & $-0.08 \pm 0.54$ & $0.15 \pm 0.53$ & 1.61 & & & 0.112 \\
\hline $\begin{array}{c}\text { Mean follow-up global } \\
\text { cognitive score } \pm \text { SD }\end{array}$ & $-0.12 \pm 0.53$ & $-0.19 \pm 0.55$ & $0.07 \pm 0.41$ & 1.88 & & & 0.064 \\
\hline
\end{tabular}

$A A$ amino acid, $A p o E$ apoliprotein $\mathrm{E}, A R T$ antiretroviral therapy, SD standard deviation

Parametric and non-parametric data are represented as mean \pm SD and median and interquartile range respectively

${ }^{a}$ Viral load comparisons included the 38 participants with a viral load of greater than or equal to 40 , the lower limit of sensitivity of the assay

b Amino acid data was available for 66 participants

c ApoE $\varepsilon 4$ allele comparison included the 63 participants for whom genotype information was available 


\section{Change in global cognitive score analyses}

Repeated measures analyses indicated that CTQ-SF score was significantly associated with decreased global cognitive scores over the 1-year study period with each unit increase in CTQ-SF score associated with a $3.88 \times 10^{-3}$ decrease in global cognitive score $(p=0.039)$ (Fig. 1). No significant effects of ApoE isoform or AA risk variants on global cognitive function were found. Test statistics for study variables are summarised in Additional file 1: Table S1. Comparing model fit revealed that including the interactive effects of ApoE4, CT, AA41 and AA55 explained significantly more of the variance in cognitive function (Akaike information criterion reduced from 56.28 to $54.69, \mathrm{p}=0.042$ ). Factor interaction effects on model fit are summarised in Additional file 2: Table S2.

\section{Discussion}

Our study examined the contribution of variation in ApoE and $\mathrm{Vpr}$ to change in cognitive function over time in a unique cohort of South African women with variable exposure to CT. In keeping with previous studies, we found that CT experience was associated with a decline in global cognitive scores over the course of one year $[20,21]$. Though the estimated effect of CTQ-SF score on global cognitive score was small, it is possible that the influence of high $\mathrm{CT}$ exposure acting over a prolonged period may produce clinically meaningful effects. Drawing on the findings of Dampier et al. [11], we generated risk scores based on Vpr AA variation. Our analyses indicated that including the interactive effects of ApoE, CTQ score and AA41 and AA55 risk variants explained significantly more of the variance in global cognitive scores over the 1-year study period. Such higher order interactive effects may be due to common pathophysiological mechanisms shared by these factors, such as inflammation, oxidative stress, and altered synaptic plasticity and glucocorticoid signalling, which are implicated in HAND pathogenesis $[15,16,31-39]$. These factors may interact to facilitate disease progression. For example, Vpr influences both host and viral gene transcription through its role as a coactivator of glucocorticoid receptors [40]. Thus, CT-induced changes to glucocorticoid receptor mRNA expression may in turn affect HIV pathophysiology through a Vpr-dependent mechanism [41]. The ApoE $\varepsilon 4$ isoform has been suggested to mediate the effects of CT on later life mental health and cognition [42, 43]. Finally, both AA41 and AA55 are included in the second alpha helix of $\mathrm{Vpr}$, a region of the protein associated with activation of viral transcription as well as cellular apoptosis, both of which are likely important in HIV-related neuropathogenesis [44]. Though our results are in keeping with the multifactorial aetiology of HAND,

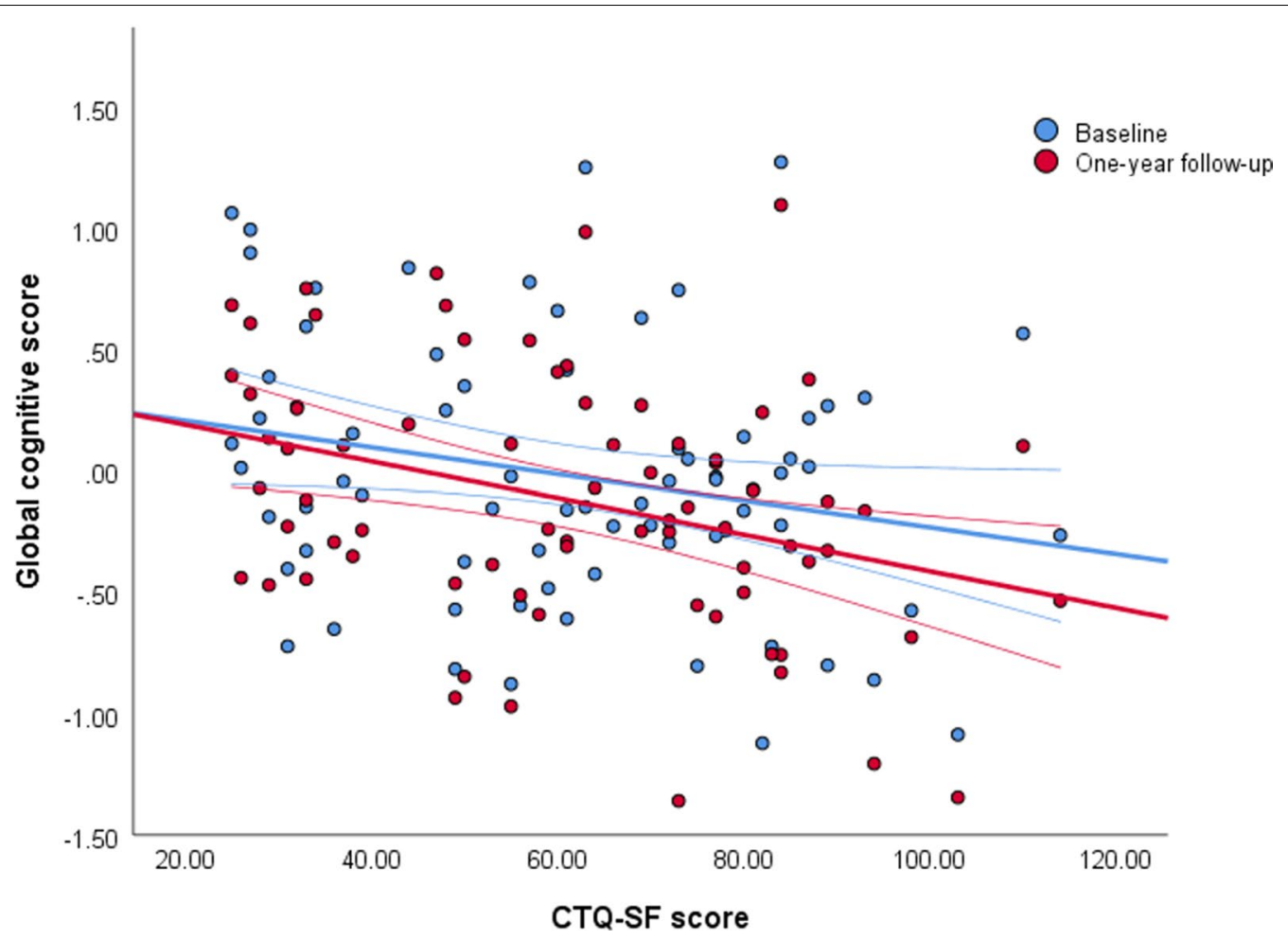

Fig. 1 Childhood trauma was significantly associated with decreased global cognitive scores over the 1-year study period. Each unit increase in CTQ-SF score was associated with a $3.88 \times 10^{-3}$ decrease in global cognitive score $(p=0.039)$ 
further studies in larger sample sizes will be required to unpack these interactions, determine their effect size and ultimately their clinical significance.

\section{Limitations}

The NP battery provides information on seven cognitive domains and thus our use of a global score will not reveal domain-specific effects. Though we found a reduction in cognitive scores over one year, the clinical significance of this decline is uncertain as both baseline and follow-up cognitive scores were within normal range. Nevertheless, the drop in scores is concerning considering that most women were on ART. Several confounding factors potentially affect $\mathrm{CT}$ measurement. As a retrospective self-report measure, the CTQ-SF may be influenced by subjective factors such as memory and recall bias [45]. We used the CTQ-SF total score in our regression models and therefore cannot determine whether specific subtypes of CT produce differential effects on cognitive performance. It is possible that additional covariates not included in our study, such as HIV-related comorbidities, may affect cognitive scores. Our findings are also not necessarily applicable to men. We grouped individuals hetero- and homozygous for the $\varepsilon 4$ isoform, and thus cannot determine whether dose-response effects could influence global cognitive scores. Finally, our relatively small sample size may be insufficient to identify relationships between our predictor variables and change in cognitive function, especially given the rarity of certain genetic variants, such as AA37 I, in our study group.

Nevertheless, these findings support the influence of CT on neurocognitive function and suggest that host and viral genetic factors interact to influence cognitive function in HIV. This study has several strengths. We used longitudinal data, an important consideration in examining the development of disorders. Our study was conducted in a population that is disproportionately affected by HIV. Females comprise the majority of the approximately 7.52 million seropositive individuals in South Africa [46]. Furthermore, $\mathrm{CT}$ is common in South Africa, including among people living with HIV $[47,48]$. We suggest future studies explore the contributions of ApoE, Vpr and CT to HAND, using larger sample sizes, which include both men and women.

\section{Supplementary information}

Supplementary information accompanies this paper at https://doi. org/10.1186/s13104-019-4869-9.

Additional file 1: Table S1. Predictive value of variables on one-year global cognitive scores.

Additional file 2: Table S2. Predictive value of interactions on one-year global cognitive scores.
Abbreviations

AA: amino acid; ApoE: apolipoprotein E; ART: antiretroviral therapy; CT: childhood trauma; CTQ-SF: Childhood Trauma Questionnaire-Short Form; HAND: HIV-associated neurocognitive disorders; NP: neuropsychological; PCR: polymerase chain reaction; Vpr: viral protein $\mathrm{R}$.

\section{Acknowledgements}

Not applicable.

\section{Authors' contributions}

The study was conceived by GS, SE, SMJH and SS. Clinical data was gathered by GS. LC, OV and SE conducted the genetic analyses. JSW performed the statistical analyses and wrote the first draft of the manuscript. All authors assisted with the interpretation of data and provided critical input to the manuscript. All authors read and approved the final manuscript.

\section{Funding}

This study was supported by a CFAR grant awarded to SS ("Biological Endophenotypes of HIV and Childhood Trauma: A Genetics, Cognitive and Imaging study"), Grant Number P30 Al036214. JSW, GS, SMJH and SS are supported by the South African Research Chair in PTSD from the Department of Science and Technology and the National Research Foundation. SMJH and SS are supported by a South African Medical Research Council "SHARED ROOTS" Flagship Project, grant MRC-RFA-FSP-01-2013/SHARED ROOTS. SE is supported by the National Health Laboratory Service (NHLS) Research Trust Grant Ref-004_94657, the South African Medical Research Council "Tygerberg Collaborating Centre for HIV Laboratory Research (TygHIVLab)", Ref-S004116 and the Poliomyelitis Research Foundation (PRF) Grant 17/07.

\section{Availability of data and materials}

The datasets generated and/or analysed during the current study are available from the corresponding author on reasonable request.

\section{Ethics approval and consent to participate}

This study was approved by the Health Research Ethics Committee at Stellenbosch University (N07/07/153) and was conducted according to the ethical guidelines and principles of the international Declaration of Helsinki. All participants and their primary guardians provided written informed consent.

Consent for publication

Not applicable.

\section{Competing interests}

The authors declare that they have no competing interests.

\section{Author details}

${ }^{1}$ Department of Psychiatry, Faculty of Medicine and Health Sciences, Stellenbosch University, Francie van Zijl Drive, Tygerberg 7505, South Africa. ${ }^{2}$ South African Medical Research Council/Stellenbosch University Genomics of Brain Disorders Research Unit, Francie van Zijl Drive, Tygerberg 7505, South Africa. 3 Joint Master in Neuroscience, Faculty of Life Sciences, University of Strasbourg, Strasbourg, France. ${ }^{4}$ Division of Medical Virology, Faculty of Medicine and Health Sciences, Stellenbosch University, Francie van Zijl Drive, Tygerberg 7505, South Africa. ${ }^{5}$ National Health Laboratory Services (NHLS), Tygerberg Coastal, Tygerberg, Western Cape Region, South Africa.

Received: 16 April 2019 Accepted: 19 December 2019

Published online: 27 December 2019
References

1. Clifford DB, Ances BM. HIV-associated neurocognitive disorder. Lancet Infect Dis. 2013;13:976-86.

2. Saloner R, Cysique LA. HIV-associated neurocognitive disorders: a global perspective. J Int Neuropsychol Soc. 2017;23:860-9.

3. UNAIDS. Global HIV \& AIDS statistics - 2018 fact sheet. 2018. http://wwW. unaids.org/en/resources/fact-sheet. Accessed 19 Feb 2019.

4. Mukerji SS, Locascio JJ, Misra V, Lorenz DR, Holman A, Dutta A, et al. Lipid Profiles and APOE4 allele impact midlife cognitive decline in HIV-infected men on antiretroviral therapy. Clin Infect Dis. 2016;63:1130-9. 
5. Wendelken LA, Jahanshad N, Rosen HJ, Busovaca E, Allen I, Coppola G, et al. ApoE $\varepsilon 4$ is associated with cognition, brain integrity, and atrophy in HIV over age 60. J AIDS. 2016;73:426-32.

6. Womersley JS, Spies G, Seedat S, Hemmings SMJ. Childhood trauma interacts with ApoE to influence neurocognitive function in women living with HIV. J Neurovirol. 2018;25:183-93.

7. Mannila MN, Mahdessian H, Franco-Cereceda A, Eggertsen G, de Faire U, Syvanen A-C, et al. Identification of a functional apolipoprotein E promoter polymorphism regulating plasma apolipoprotein $\mathrm{E}$ concentration. Arterioscler Thromb Vasc Biol. 2013;33:1063-9.

8. Burt TD, Agan BK, Marconi VC, He W, Kulkarni H, Mold JE, et al. Apolipoprotein (apo) E4 enhances HIV-1 cell entry in vitro, and the APOE 4/4 genotype accelerates HIV disease progression. Proc Natl Acad Sci. 2008; 105:8718-23.

9. Dobson CB, Sales SD, Hoggard P, Wozniak MA, Crutcher KA. The receptorbinding region of human apolipoprotein $\mathrm{E}$ has direct anti-infective activity. J Infect Dis. 2006;193:442-50.

10. Pocernich CB, Sultana R, Hone E, Turchan J, Martins RN, Calabrese V, et al. Effects of apolipoprotein $E$ on the human immunodeficiency virus protein tat in neuronal cultures and synaptosomes. J Neurosci Res. 2004;77:532-9.

11. Dampier W, Antell GC, Aiamkitsumrit B, Nonnemacher MR, Jacobson $J M$, Pirrone $V$, et al. Specific amino acids in HIV-1 Vpr are significantly associated with differences in patient neurocognitive status. J Neurovirol. 2017;23:113-24.

12. Levy DN, Refaeli Y, MacGregor RR, Weiner DB. Serum Vpr regulates productive infection and latency of human immunodeficiency virus type 1. Proc Natl Acad Sci U S A. 1994;91:10873-7.

13. Yao X-J, Mouland AJ, Subbramanian RA, Forget J, Rougeau N, Bergeron $D$, et al. Vpr stimulates viral expression and induces cell killing in human immunodeficiency virus Type 1-infected dividing jurkat T Cells. J Virol. 1998;72:4686-93.

14. Patel CA, Mukhtar M, Pomerantz RJ. Human immunodeficiency virus type 1 Vpr induces apoptosis in human neuronal cells. J Virol. 2000;74:9717-26.

15. Ferrucci A, Nonnemacher MR, Wigdahl B. Extracellular HIV-1 viral protein $R$ affects astrocytic glyceraldehyde 3-phosphate dehydrogenase activity and neuronal survival. J Neurovirol. 2013;19:239-53.

16. Torres L, Noel RJ. Astrocytic expression of HIV-1 viral protein R in the hippocampus causes chromatolysis, synaptic loss and memory impairment. J Neuroinflammation. 2014;11:53.

17. Guenzel CA, Hérate C, Benichou S. HIV-1 Vpr-a still enigmatic multitasker. Front Microbiol. 2014. https://doi.org/10.3389/fmicb.2014.00127.

18. De Bellis MD, Keshavan MS, Clark DB, Casey BJ, Giedd JN, Boring AM, et al. Bennett Research Award. Developmental traumatology Part II: Brain development. Biol Psychiatry. 1999;45:1271-84.

19. Edwards VJ, Holden GW, Felitti VJ, Anda RF. Relationship between multiple forms of childhood maltreatment and adult mental health in community respondents: results from the adverse childhood experiences study. Am J Psychiatry. 2003;160:1453-60.

20. Spies G, Fennema-Notestine C, Archibald SL, Cherner M, Seedat S. Neurocognitive deficits in HIV-infected women and victims of childhood trauma. AIDS Care. 2012;24:1126-35.

21. Spies G, Ahmed-Leitao F, Fennema-Notestine C, Cherner M, Seedat S. Effects of HIV and childhood trauma on brain morphometry and neurocognitive function. J Neurovirol. 2016;22:149-58.

22. Spies G, Fennema-Notestine C, Cherner M, Seedat S. Changes in cognitive function in women with HIV infection and early life stress. AIDS Care. 2017:29:14-23.

23. Sheehan DV, Lecrubier $Y$, Sheehan $K H$, Amorim $P$, Janavs J, Weiller E, et al. The Mini-International Neuropsychiatric Interview (M.I.N.I.): the development and validation of a structured diagnostic psychiatric interview for DSM-IV and ICD-10. J Clin Psychiatry. 1998;59(Suppl 20):22-33 (Quiz 34-57).

24. Heaton RK, Cysique LA, Jin H, Shi C, Yu X, Letendre S, et al. Neurobehavioral effects of human immunodeficiency virus infection among former plasma donors in rural China. J Neurovirol. 2008;14:536-49.

25. Bernstein DP, Fink L. Manual for the childhood trauma questionnaire: a retrospective self-report. The Psychological Corporation. New York: Harcourt Brace; 1998.
26. Struck D, Lawyer G, Ternes A-M, Schmit J-C, Bercoff DP. COMET: adaptive context-based modeling for ultrafast HIV-1 subtype identification. Nucleic Acids Res. 2014;42:e144

27. Schultz A-K, Zhang M, Bulla I, Leitner T, Korber B, Morgenstern B, et al. jpHMM: improving the reliability of recombination prediction in HIV-1. Nucleic Acids Res. 2009;37:W647-51.

28. Pineda-Peña A-C, Faria NR, Imbrechts S, Libin P, Abecasis AB, Deforche K, et al. Automated subtyping of HIV-1 genetic sequences for clinical and surveillance purposes: performance evaluation of the new REGA version 3 and seven other tools. Infect Genet Evol. 2013;19:337-48.

29. Siepel AC, Halpern AL, Macken C, Korber BT. A computer program designed to screen rapidly for HIV type 1 intersubtype recombinant sequences. AIDS Res Hum Retroviruses. 1995;11:1413-6.

30. R Core Team. R: a language and environment for statistical computing. Vienna: R Foundation for Statistical Computing; 2018. https://www.Rproject.org/.

31. Carlson M, Earls F. Psychological and neuroendocrinological sequelae of early social deprivation in institutionalized children in Romania. Ann NY Acad Sci. 1997;807:419-28.

32. Kino T, Gragerov A, Kopp JB, Stauber RH, Pavlakis GN, Chrousos GP. The HIV-1 Virion-associated protein Vpr Is a Coactivator of the Human Glucocorticoid Receptor. J Exp Med. 1999;189:51-62.

33. Ihara Y, Hayabara T, Sasaki K, Kawada R, Nakashima Y, Kuroda S. Relationship between oxidative stress and apoE phenotype in Alzheimer's disease. Acta Neurol Scand. 2000;102:346-9.

34. Shea TB, Rogers E, Ashline D, Ortiz D, Sheu M-S. Apolipoprotein E deficiency promotes increased oxidative stress and compensatory increases in antioxidants in brain tissue. Free Radic Biol Med. 2002;33:1115-20.

35. Danese A, Pariante CM, Caspi A, Taylor A, Poulton R. Childhood maltreatment predicts adult inflammation in a life-course study. Proc Natl Acad Sci U S A. 2007;104:1319-24

36. Chen Y, Durakoglugil MS, Xian X, Herz J. ApoE4 reduces glutamate receptor function and synaptic plasticity by selectively impairing ApoE receptor recycling. Proc Natl Acad Sci. 2010;107:12011-6.

37. Monroy E, Hernández-Torres E, Flores G. Maternal separation disrupts dendritic morphology of neurons in prefrontal cortex, hippocampus, and nucleus accumbens in male rat offspring. J Chem Neuroanat. 2010:40:93-101.

38. Boeck C, Koenig AM, Schury K, Geiger ML, Karabatsiakis A, Wilker S, et al. Inflammation in adult women with a history of child maltreatment: the involvement of mitochondrial alterations and oxidative stress. Mitochondrion. 2016;30:197-207.

39. Trusca VG, Fuior EV, Fenyo IM, Kardassis D, Simionescu M, Gafencu AV. Differential action of glucocorticoids on apolipoprotein $\mathrm{E}$ gene expression in macrophages and hepatocytes. PLOS ONE. 2017;12:e0174078.

40. Sherman MP, de Noronha CMC, Pearce D, Greene WC. Human Immunodeficiency virus type $1 \mathrm{Vpr}$ contains two leucine-rich helices that mediate glucocorticoid receptor coactivation independently of its Effects on G2 cell cycle srrest. J Virol. 2000;74:8159-65.

41. McGowan PO, Sasaki A, D'Alessio AC, Dymov S, Labonté B, Szyf M, et al. Epigenetic regulation of the glucocorticoid receptor in human brain associates with childhood abuse. Nat Neurosci. 2009;12:342-8.

42. Savitz J, van der Merwe L, Stein DJ, Solms M, Ramesar R. Genotype and childhood sexual trauma moderate neurocognitive performance: a possible role for brain-derived neurotrophic factor and apolipoprotein $\mathrm{E}$ variants. Biol Psychiatry. 2007;62:391-9.

43. Park S, Nam Y-Y, Sim Y, Hong JP. Interactions between the apolipoprotein E $\varepsilon 4$ allele status and adverse childhood experiences on depressive symptoms in older adults. Eur J Psychotraumatol. 2015;6:25178.

44. Morellet N, Roques BP, Bouaziz S. Structure-function relationship of Vpr: biological implications. Curr HIV Res. 2009;7:184-210.

45. Carpenter LL, Tyrka AR, Ross NS, Khoury L, Anderson GM, Price LH. Effect of childhood emotional abuse and age on cortisol responsivity in adulthood. Biol Psychiatry. 2009:66:69-75.

46. Stats SA. Statistical release: mid-year population estimates 2018. 2018.

47. Jewkes RK, Dunkle K, Nduna M, Jama PN, Puren A. Associations between childhood adversity and depression, substance abuse and HIV and HSV2 incident infections in rural South African youth. Child Abuse Negl. 2010;34:833-41. 
48. Gibbs A, Dunkle K, Washington L, Willan S, Shai N, Jewkes R. Childhood traumas as a risk factor for HIV-risk behaviours amongst young women and men living in urban informal settlements in South Africa: a crosssectional study. PLoS ONE. 2018;13:e0195369.

\section{Publisher's Note}

Springer Nature remains neutral with regard to jurisdictional claims in published maps and institutional affiliations.
Ready to submit your research? Choose BMC and benefit from:

- fast, convenient online submission

- thorough peer review by experienced researchers in your field

- rapid publication on acceptance

- support for research data, including large and complex data types

- gold Open Access which fosters wider collaboration and increased citations

- maximum visibility for your research: over $100 \mathrm{M}$ website views per year

At BMC, research is always in progress.

Learn more biomedcentral.com/submissions 